\title{
The effects of living wage laws on low-wage workers and low-income families: What do we know now?
}

\author{
David Neumark ${ }^{1 *}$, Matthew Thompson ${ }^{2}$ and Leslie Koyle ${ }^{3}$
}

\author{
* Correspondence: \\ dneumark@uci.edu \\ ${ }^{1} \mathrm{UCI}, \mathrm{NBER}$, and IZA, Irvine, CA, USA \\ Full list of author information is \\ available at the end of the article
}

\begin{abstract}
We provide updated evidence on the effects of living wage laws in U.S. cities, relative to the earlier research covering only the first six or seven years of existence of these laws. There are some challenges to updating the evidence, as the CPS data on which it relies changed geographic coding systems in the mid-2000s. The updated evidence is broadly consistent with the conclusions reached by prior research, including a recent review of that earlier evidence. Living wage laws reduce employment among the least-skilled workers they are intended to help. But they also increase wages for many of them. This implies that living wage laws generate both winners and losers among those affected by them. For broader living wage laws that cover recipients of business or financial assistance from cities, the net effects point to modest reductions in urban poverty.

JEL codes: J23, $J 38$

Keywords: Living wages, Wages, Employment, Poverty
\end{abstract}

\section{里

\section{Introduction}

The first living wage law was passed in Baltimore in 1994, and living wage laws quickly spread - in less than two decades - to more than 140 jurisdictions in the United States, including many of the nation's largest cities that together comprise a significant share of the nation's urban population. The early wave of research on living wages used data covering only the initial years of the diffusion of the policy through U.S. cities, typically ending in 2002 or even earlier (see, e.g., Adams and Neumark (2004a, 2005a)). Given the paucity of observations used in the original research, and given that we now have many more years of observation on the effects of living wages in the cities that passed them earlier, and new living wage laws in numerous cities, it is an opportune time to update the evidence on the effects of living wage laws, and that is the goal of this paper.

Living wage laws have two central features. First, they typically impose a wage floor that is higher - and often much higher - than traditional federal and state minimum wages. For example, as of the end of 2009 (the end of the sample period in this paper) the minimum wage in California, Illinois, and Massachusetts was $\$ 8$, whereas the living wage was $\$ 12.79$ in Boston, \$11.03 in Chicago, and \$10.30 in Los Angeles. ${ }^{1}$ Second, coverage by living wage laws is generally quite narrow, but also varies across cities. Most commonly, cities impose wage

(c) 2012 Neumark et al.; licensee Springer. This is an Open Access article distributed under the terms of the Creative Commons Attribution License (http://creativecommons.org/licenses/by/2.0), which permits unrestricted use, distribution, and reproduction in any medium, provided the original work is properly cited. 
floors only on companies under contract with the city (sometimes including non-profits). Early estimates of the share of workers covered by "contractor-only" living wage laws in cities with living wage laws hovered around $1 \%{ }^{2}$ Other cities also impose the wage floor on companies receiving business assistance from the city, almost always in addition to coverage of city contractors. These "business assistance laws" cover firms receiving financial assistance, tax abatements, grants, low interest loans, and many other forms of government assistance from cities. Finally, a handful of cities require that city employees or employees of municipal leaseholders be paid the mandated living wage. ${ }^{3}$

The prior research on living wages focused on their effects on workers and their families. The focus on workers and families stems from what is nearly always stated as the central goal of living wages - to raise incomes of low-wage workers in order to reduce urban poverty. If living wages help reduce poverty, they do this via two mechanisms. First, they raise wages of the low-wage employees of covered businesses - and perhaps also of other workers who might be affected by the presence of a living wage law in a city. And second, the gains from these higher wages for low-wage workers accrue to low-income families.

While raising wages of low-wage workers via living wages may seem a natural way to fight poverty, there are two reasons why such mandates may not help to achieve this goal, aside from the fact that they do not cover many workers. First, economic theory predicts that because a mandated wage increase operates essentially as a tax on the use of lower-skilled labor, living wages may discourage the use of such labor. Thus, whatever wage gains accrue to workers who retain their jobs must be offset against potential employment (or hours) declines for other workers. The question of whether living wage laws reduce employment of covered workers is probably the central question that has been contested in the research literature. $^{4}$

Second, living wages may not effectively target low-income families. Broadly speaking, lowwage workers in the United States have large shares from two groups. The first is very young workers who have not yet acquired many labor market skills but who are likely to escape low-wage work as they acquire skills. The second is low-skilled adults who remain mired in low-wage jobs and who - as adults - are much more likely to be in poor families. ${ }^{5}$ Thus, whether living wages help reduce poverty depends on wage gains and employment losses, and the extent to which the gains from living wages (the wage increases) as opposed to the costs (job loss) fall on individuals in poor families. There is also an issue of the interaction between changes in labor market earnings and changes in government benefits, which we take up in this paper.

There is a critical point in the discussion of whether living wages help poor and lowincome families that bears emphasizing. Standard economic theory predicts that a mandated wage floor like a living wage will reduce employment. However, how a mandated wage floor affects the distribution of income, and poor families in particular, is purely an empirical question. One can be absolutely convinced, from the theory or, preferably, the evidence, that living wages reduce employment. But this provides no reason to believe on a priori grounds that a living wage would fail to help poor families. The existence of job losses is perfectly compatible with living wages doing more for poor families via the wage increases that some workers get than the job losses that others experience. There is, in other words, no logical deduction from standard economic theory to the conclusion that living wages (or minimum wages) could not help the poor. The latter question is a purely empirical one. 
The research we present in this paper uses data and methods that, based on our review of the past research literature, are best suited for estimating effects of living wage laws, largely following Adams and Neumark (2005a). However, these methods and the data on which they rely have been contested, so to explain why we continue to use these data and methods, we provide a summary of the criticisms they have encountered and an explanation of why we view these methods and data as the best way to study the effects of living wages, in light of the available data. As in the existing literature, our focus is on the effects of living wage laws on low-wage workers and low-income families.

\section{Past research on living wages}

This study uses "before-and-after" comparisons of labor market outcomes in U.S. cities that implemented living wage laws and cities that did not. Such studies became possible once a sufficient number of U.S. cities implemented living wage laws.

\section{Simulation studies}

There was an earlier wave of "impact" or "simulation" studies that tried to assess the consequences of living wage laws before they were implemented in cities. ${ }^{6}$ These simulation studies used data describing the labor market in a particular city, and assumptions about the behavioral responses of firms and workers to the proposed living wage. Naturally, the answers depend strongly on the assumptions - most importantly, but not exclusively, on the assumed employment response to the higher wage mandated by the living wage law. As a consequence, these simulation studies are less compelling than research using standard methods of policy evaluation based on treatment and comparison groups. However, the simulation studies do have a role to play, in that they can capture unique aspects of the city's labor market or its proposed living wage law. Nonetheless, they should be informed by evidence from the experience of other cities that have implemented living wage laws, rather than relying on assumed behavioral responses that could be chosen in a way that dictates the findings.

\section{Longitudinal evidence}

After the passage of some time following enactment of the first living wage laws, and some of the earliest simulation studies of living wages, Neumark and Adams (2003a, 2003b) provided the first estimates of the effects of living wages on workers and families, based on longitudinal comparisons between cities where the mandates were and were not introduced. These studies are explained in some detail, to set the stage for the discussion of criticism of the data and methods they used, and for the updated analysis that follows.

The Neumark and Adams studies covered the inception of living wage laws in the mid-1990s through 2002, using Current Population Survey (CPS) data from the monthly Outgoing Rotation Group (MORG) files, which capture individual wages and employment, and the March Annual Social and Economic Supplement (ASEC) files, which capture family income. The analysis was done at the level of Metropolitan Statistical Areas (MSAs) or Primary Metropolitan Statistical Areas (PMSAs), based on where CPS respondents reside. (The CPS does not tell us where people work.) MSAs/PMSAs include areas surrounding the major cities whose living wage laws are studied; but MSA residents who live in suburbs tend to work in the central city, where jobs are concentrated (Cervero, 2002). 
The studies estimate the effects of living wage laws on wages and employment at the low end of the wage or skill distribution (the bottom decile in each city-month cell), and on family income relative to needs. The effects of living wages are identified from differential changes in outcomes in cities that implemented or raised a living wage relative to cities that did not - a difference - in - differences (DD) research design. Neumark and Adams also distinguished between contractor-only and broader business assistance living wage laws, and it was only the latter that turned out to matter. ${ }^{7}$

Overall, the evidence indicated that living wages raise wages at the bottom of the wage distribution. For those in the bottom decile in each city, when all living wage laws are treated uniformly, the evidence on wages points to an elasticity with respect to the living wage of 0.04 at a lag of 12 months, which is not statistically significant at the $10 \%$ level. However, when living wages are classified as contractor-only or business assistance living wage laws, the effects (on all outcomes) are considerably sharper for the living wage laws with business assistance provisions. ${ }^{8}$ The evidence pointed to a statistically significant impact (at the 10\% level) on wages only of business assistance laws, with an estimated elasticity of 0.07. In contrast, the estimated impact of contractor-only laws is small and statistically insignificant.

The employment effects are estimated using the same basic empirical framework. Because employment is a discrete outcome, the models estimated are linear probability models. Also, given that wages are not observed for the non-employed, wages are imputed for everyone, and the parallel to focusing on low-wage workers in the wage analysis is to focus on low-skill (i.e., low predicted wage) workers in the employment analysis. For living wages generally, the estimated employment effect on those in the bottom decile of the predicted wage distribution is negative and significant at the $5 \%$ level at a lag of 12 months, paralleling where the wage results were detected. The estimated coefficient of -0.053 implies that a $100 \%$ (or one log unit) increase in the living wage reduces employment by 5.3 percentage points. Given an employment rate of $43.4 \%$ in the lowest decile of the imputed wage distribution in the data used in this regression, this represents a $12 \%$ employment reduction, or an elasticity of $-0.12 .{ }^{10}$ When separate effects are estimated for business assistance and contractor-only living wage laws, both estimates are negative, but there is a significant employment effect only for business assistance living wage laws, with an elasticity of -0.17 , and a much smaller (and insignificant) estimate for contractor-only laws. ${ }^{11,12}$

In this analysis it is assumed that changes in living wages are exogenous - that is, the policy changes are not themselves responses to changes in labor market outcomes. Ruling out reverse causality is difficult, because there is unlikely to be an instrumental variable that predicts the adoption (or level) of living wages and that also varies over time; given that the model includes city dummy variables, the variation over time is required. There are, though, some approaches to this problem in the existing research. For example, in Adams and Neumark (2005b), the experiences of cities enacting living wages laws were compared only with cities in which living wage laws were approved but then overturned or annulled by judicial rulings, legislative decisions, etc. The virtue of this approach is that in both types of cities living wages were "almost adopted," so that the factors that might have influenced policy can more effectively be held constant. The estimated effects of living wages are little changed relative to the estimates using all control cities. In addition, the models control for prior trends that could reflect differences in changes in labor 
market outcomes for low-wage or low-skilled workers - which could be either spuriously correlated with living wage variation, or help explain it.

The evidence on wage and employment effects sets the stage for weighing these competing effects in how living wage laws affect poverty. To examine the impact of living wages on poverty, linear probability models are estimated for the full sample of families from the CPS ASEC files covering 1995 through 2001. The dependent variable is a dummy variable equal to one if a family's income falls below the federal government's threshold for poverty, and zero otherwise. The evidence yields negative point estimates (implying poverty reductions) for both types of living wage laws, but only the estimated effect of business assistance living wage laws is statistically significant (at the 10\% level). For business assistance living wage laws, the estimated coefficient is -0.024 , which implies that a one log unit increase in the living wage reduces the poverty rate by $2.4 \%$. Relative to an $18.6 \%$ poverty rate, this represents a $12 \%$ reduction, or an elasticity of -0.12 . This seems like a large effect, given the wage elasticity for low-wage workers below 0.1. Living wages cannot lift families from well below the poverty line to well above it. But living wages may help nudge families over the poverty line, and the estimated average wage effects are likely manifested as much larger gains concentrated on a possibly quite small number of workers and families. Thus, even coupled with some employment reductions, living wages can lift a detectable number of families above the poverty line.

\section{Assessment of the earlier literature}

Comprehensive reviews of the research literature through the initial phase of the passage of living wage laws were provided in Adams and Neumark (2004a and 2004b). These reviews summarize previous evidence, but also provide a review and critique of other research on the impact of living wages. Holzer (2008) reviewed the living wage literature more recently, although this review focuses almost entirely on the same research (extending through 2005), as there was little additional research done since. A comprehensive and more up-to-date review of the living wage literature that covers a few recent studies is provided in Charles River Associates (2011), from which the research in this paper was drawn.

Holzer's (2008) review of the Neumark and Adams studies, as well as other studies that tried to estimate the observed impact of living wages based on longitudinal variation, reached conclusions very much parallel those of Neumark and Adams: ${ }^{13}$

"Living wage laws have both modest benefits and modest costs for low-wage workers. Living wage laws raise the wages of the lowest-wage workers. They may also result in ... modest reductions in poverty. However, they lead to modest reductions in employment for the lowest-wage workers ... Living wage laws can be useful but meaningful increases in the earnings of low-wage workers and reductions in poverty require more powerful public policies" (pp. 2-3).

\section{Criticisms of methods and data}

Because the goal of this paper is to update these estimates, it is useful to consider the key issues that have been raised regarding the methods and the data on which they rely. There are four key criticisms. The first criticism is that the estimates of disemployment effects obtained in the longitudinal studies are simply too large to be plausible. The second criticism is that the evidence of stronger effects of business assistance living wage laws cannot be 
reconciled with the fact (which is asserted) that business assistance provisions cover almost no workers. The third criticism is that the CPS data used in the longitudinal analyses do not provide large enough samples to detect effects of living wage laws. And the fourth criticism is that the econometric methods used are incorrect. We address each of these in turn. ${ }^{14}$

\section{Implausible estimates}

Fairris and Reich (2005, p. 10) claim that estimates in Adams and Neumark (2005a) indicate that $91 \%$ of affected workers would lose their jobs, implying employment elasticities that are huge and simply implausible, thus dismissing the evidence out of hand. This claim, however, is simply incorrect. Adams and Neumark consider a $35 \%$ business assistance living wage increase. Given their estimated employment elasticity for those in the bottom decile of the skill distribution (the affected workers) of -0.076 , and an employment rate in this group of $44 \%$, the employment effect implied by the increase they consider is $-6 \%$, an estimate that cannot be used to dismiss the methods out of hand as providing implausible estimates. ${ }^{15}$

\section{Business assistance living wage laws cannot matter much}

Some criticisms claim that hardly any workers were actually affected by the business assistance provisions of living wage laws, which would be difficult to reconcile with the findings that business assistance living wage laws matter more than contractor-only laws (Pollin et al., (2008, pp. 242-6)). There was and remains uncertainty over how many workers are covered by business assistance living wage laws, but the evidence does not support the claim that hardly any workers were affected.

Fairris et al. (2005) suggest that the number of workers employed by business assistance recipients whose wages were affected by the Los Angeles living wage law as of their 2001-2003 survey was only around 1,100 (their Tables 2.1 and 2.5). However, because the survey covers contractors only, it is not representative of assistance recipients, and presumably misses most of them. ${ }^{16}$ Moreover, in 2003, Los Angeles expanded its living wage policy to apply to employees of real estate developers that receive public subsidies (and their subcontractors), although not their tenants. Finally, Luce's (2004) book on the implementation of living wage laws concludes that business assistance coverage was extensive and was effectively extended beyond those workers explicitly covered by the living wage law:

"In early 1998, coalition members got word of city negotiations over a large redevelopment project in Hollywood ... with major developer TrizecHahn ... In the end, TrizecHahn agreed not only to pay living wages and benefits to its workers but also agreed to require retailers leasing space in the development to pay living wages and give first priority in hiring to Hollywood residents. In addition, the living wage coalition won an agreement that required seven hundred to eight hundred of the staff positions at the new development to be unionized. The coalition went on to win similar agreements for other major developments in the city" (Luce, 2004, p. 122, italics added). ${ }^{17}$

Moreover, in a recent living wage study Lester and Jacobs (2010) explicitly try to identify a subset of cities that were "effectively implementing business assistance living wage laws" (p. 1), and specifically include three cities - Los Angeles, Minneapolis, and Oakland (their Table C) - for which Pollin et al. (2008) claimed hardly any workers were affected. Lester and Jacobs concur that we should expect larger effects from business assistance provisions 
of living wage laws: "[B]usiness assistance living wage laws are the type of economic development wage standard likely to have the most widespread effect on employment" (p. 3).

In addition to the issue of coverage, there are other reasons that business assistance living wage laws could have larger effects. The kinds of mechanisms described above by Luce (2004) - operating outside the specific channels established by the living wage law, perhaps through changing community norms - could generate additional impacts of business assistance living wage laws. In addition, the two types of laws may have qualitatively different effects, and the characteristics of contractor-only laws may make it more likely that their effects can be mitigated or avoided. First, contractor-only laws typically require that employers pay the mandated wage for work done as part of the contract. Assuming that contractors' employees do some other work in addition to city contracts, employers can mitigate the costs of complying with living wage laws by reallocating their higher-skilled or higher-seniority (and therefore higher-wage) labor to the contract work and their lower-wage labor to the non-contract work, or even by reducing wages on non-contract work. In contrast, an establishment created with the help of business assistance from a city would appear to have no choice but to pay all employees no less than the mandated living wage for all of their work. ${ }^{18}$ Second, contractors may be able to pass through a large share, if not all, of their increased costs to cities, given that they are selling their services to the city and contractors compete on equal footing. In contrast, business assistance recipients compete in private markets; consider, for example, a mall developed with such assistance, in which the stores have to compete with similar stores elsewhere that are not bound by living wage requirements. ${ }^{19}$

Nonetheless, we acknowledge that it is difficult to gauge how many workers are covered by business assistance laws, as there is typically little hard data on this. We point readers to a recent study of the proposed implementation of a new business-assistance living wage law in New York City (Neumark et al., forthcoming). This study did extensive data work to combine city administrative data and confidential establishment-level data from the Quarterly Census of Employment and Wages to get much better measurement of workers who would have been affected by this specific law. This analysis resulted in an estimate that $12.9 \%$ of workers earning less than $\$ 10$ per hour (and living in the city) would have been affected by the proposed law, or about $1.2 \%$ of the entire workforce of city residents. Interpreted in light of the longitudinal estimates focusing on the bottom decile of the wage or skill distribution, this estimate suggests that about $12 \%$ of workers in that bottom decile would have been affected. Given this estimate, a wage elasticity of 0.07 with respect to business assistance living wages (as reported above) may be in the right ballpark, if we think about a living wage law raising the effective wage floor by about $50 \%$. The employment elasticity of -0.17 noted above is probably a little more outside the likely range we might expect, if we consider that this estimate is in the typical range of estimated minimum wage-employment elasticities, and minimum wages usually affect a larger share of workers studied (e.g., teenagers). In addition, the proposed New York law was extensive, so reconciling the existing estimates of the effects of business assistance living wage laws with coverage probably does require assuming that business assistance living wage laws have broader effects than on those workers directly affected.

\section{The CPS data do not provide large enough samples}

A third criticism is that the CPS data - which we also use in this study - do not deliver sample sizes sufficiently large to detect effects of living wage laws (Brenner et al., 2002; 
Pollin et al., 2008). But the calculation used to make this argument is in error. ${ }^{20}$ Moreover, the bottom line is that a standard research design for estimating policy effects produces estimates of non-negligible effects that, insofar as theory makes predictions, are consistent with expectations. It is hard to reconcile this evidence with claims that the CPS data could not possibly detect effects of living wages; indeed such arguments are usually made to counter failure to find a significant effect. ${ }^{21}$

\section{The econometric methods are flawed}

A final criticism is that the econometric methods are incorrect. Neumark and Adams focus attention on models estimated for the workers in the bottom decile of the wage distribution. Brenner et al. (2002) argued that this approach leads to spurious evidence of living wage effects, and that a quantile regression approach should be used to avoid this bias. They then estimated a quantile regression for the 10th percentile, with a striking difference in results. Whereas the initial Neumark and Adams estimate of the wage effect below the 10th percentile (which they replicate) was 6.95 (and significant) - implying an elasticity of wages in this range with respect to living wages of 0.7 - the quantile regression estimate was only onetenth as large, at 0.74 (and insignificant).

This is a misuse of quantile regression, however - one which should not replicate the positive wage effects, and would not detect a true positive wage effect. Neumark and Adams' regression looks at the wage distribution without conditioning on skill, picks out those below the 10th percentile in each city-month cell, and then estimates the effects of living wages on wages for them - asking whether living wage laws increase the wages of the lowest wage workers (those below the 10th percentile). In contrast, a quantile regression conditional on skill asks whether living wages increase the wages of those at the $10^{\text {th }}$ percentile relative to wages of workers with similar characteristics, whether these workers earn high or low wages. But because living wage laws are simply floors on absolute wages, there is no reason to expect a general shift in relative wages within skill groups. Indeed, when Adams and Neumark (2005a) estimate a quantile regression for the $10^{\text {th }}$ percentile without conditioning on skill, the estimated wage effect is similar to their original estimate.

This discussion indicates that the data and methods used in the earlier longitudinal studies of the effects of living wages are not flawed. They are therefore used in our research updating evidence on the effects of living wages, as described in the following section.

\section{The effects of living wage laws: updating the evidence CPS data}

We update the earlier longitudinal analyses using CPS data through 2009, which was the latest year available at the time this research was done (the period covered by the ASEC files extended through 2008, versus 2009 for the MORG files). A substantial complication is introduced by changes in the geographic classification of areas in the CPS. Geographic information in the CPS is reported by place of residence according to a classification system of "statistical areas" based on population density and commuting patterns. Before 2005, the system was based on four-digit Federal Information Processing Standard (FIPS) codes for the MSA, PMSA, or Consolidated Metropolitan Statistical Area (CMSA). In 2005, it changed to one based on Core-Based Statistical Areas (CBSA), which have five-digit FIPS codes. 
The pre-2005 MSA/PMSA/CMSA definitions grouped counties (or cities and towns in New England) based around one or more "central cities" that can cross state lines. Geographically-interconnected PMSAs are combined to form CMSAs, of which there are 18 in the United States. The post-2005 CBSA system is based on core urban areas instead of central cities. CBSAs are classified as either Metropolitan Areas or Micropolitan Areas, based on size requirements. Larger Metropolitan Areas are subdivided into Metropolitan Divisions, which are comparable to the subdivision of CMSAs into PMSAs in the pre-2005 definitions. One or more CBSAs may be grouped together to form a Consolidated Statistical Area (CSA). The definitions of these areas pre- and post-2005 are spelled out in Table 1.

The Census Bureau provides a crosswalk mapping post-2005 CBSAs to their pre-2005 MSA/PMSA counterparts. ${ }^{22}$ The crosswalk contains 935 unique CBSAs (both Micropoli$\tan$ Areas and Metropolitan Areas), but the 2005-2009 CPS data report only 275 unique CBSAs, in large part because the CPS does not report Micropolitan Area CBSAs. Of the 275 unique CBSA FIPS codes, 245 CBSAs could be mapped directly to an MSA or CMSA using the crosswalk provided. Another 16 CBSAs were manually mapped using the New England Cities and Towns Area (NECTA) definitions based on names. ${ }^{23}$ The last step in applying the crosswalk consists of consolidating PMSAs in the pre-2005 period into CMSAs, because the post-2005 CBSAs in the CPS data do not include Metropolitan Division distinctions. All PMSAs belonging to the 18 CMSAs in the United States were therefore rolled up into their appropriate CMSAs pre- and post-2005 in order to have consistent geographic areas across time.

These steps resulted in 215 unique MSA/CMSA areas. Geographic identifiers are suppressed (for confidentiality reasons) for 35 of these - some before and some after the change in geographic classification. Again, though, this is not pertinent to our analysis, because this suppression occurs only for smaller cities that get dropped because of too few observations. Thus, we have 180 MSAs or CMSAs defined on a consistent basis over the years we study.

To assess the accuracy of geographical linkages over time, we chose five MSAs/CMSAs for which the conversion was complicated and five that were simple, and computed the shares black, Hispanic, and with low educational attainment (high school degree or equivalent), as well as weighted population estimates, over time in both the ASEC and MORG data. We wanted to check for breaks at the time of the switch in geographic classification, which could point to inconsistent geographic definitions over time. There was no indication of unusual changes surrounding the switch in geographic definitions in 2005, for either the simple or the complicated CMSA aggregations. Figure 1 provides an example of one of these analyses, focusing on the share black in the ASEC data. This share is a useful metric, because residential segregation by race implies that incorrect changes in the geographic areas would likely deliver noticeable changes in the share of the population that is black. A more problematic issue, discussed below, is the accurate measurement of the living wage in these MSAs/CMSAs, in cases where living wages are in place in only some cities in the MSA/CMSA, or differ across them.

The empirical analysis is done with individual-level data. However, the analysis requires the estimation of percentiles of the wage or predicted wage distribution for MSAs/CMSAs, by month or year. To ensure a reasonable level of accuracy in doing this, we required that an MSA/CMSA had at least 50 observations on individuals age 16-70 in all months of the 


\section{Table 1 Pre- and post-2005 geographic classification systems}

1996-2005

2005-2009

Classification: MSA, PMSA, CMSA

Counties (except in New England, which uses cities and towns) Based around one or more central cities

Population MSAs must have 50,000 or more in the central city, or a defined urbanized area of at least 50,000,
requirements: provided that the component county/counties of the MSA have a total population of at least 100,000

PMSAs must have at least one county with 100,000 population, $60 \%$ urban, 35\% residents of county work outside the county, less than 2,500 population of the largest central city of the level A MSA

Two or more PMSAs combine to form a CMSA

Inclusion Counties that include a central city of the MSA, or at least 50 percent of the population of such a city, provided the city is located in a qualified urbanized area; counties in which at least 50 percent of the population lives in the qualified urbanized area(s); outlying counties are also included if of the population lives in the qualified urbanized area(s); outlying counties are also included if
certain conditions are met (population density, 40-50\% of workers commute to the central city, etc.)

CBSA - Metropolitan Area, Micropolitan Area

Counties (except in New England, which uses cities and towns)

Metropolitan areas must have 50,000 or more in the core urban area Micropolitan areas must have 10,000-50,000 in the core urban area

Under certain conditions, one or more CBSAs may be grouped together to form a larger statistical entity known as a combined statistical area (CSA)

Core urban county, and adjacent counties that have a high degree of social and economic integration (as measured by commuting to work) with the urban core tional details, see http://www.census.gov/population/www/metroareas/mastand.html and http://www.census.gov/ 


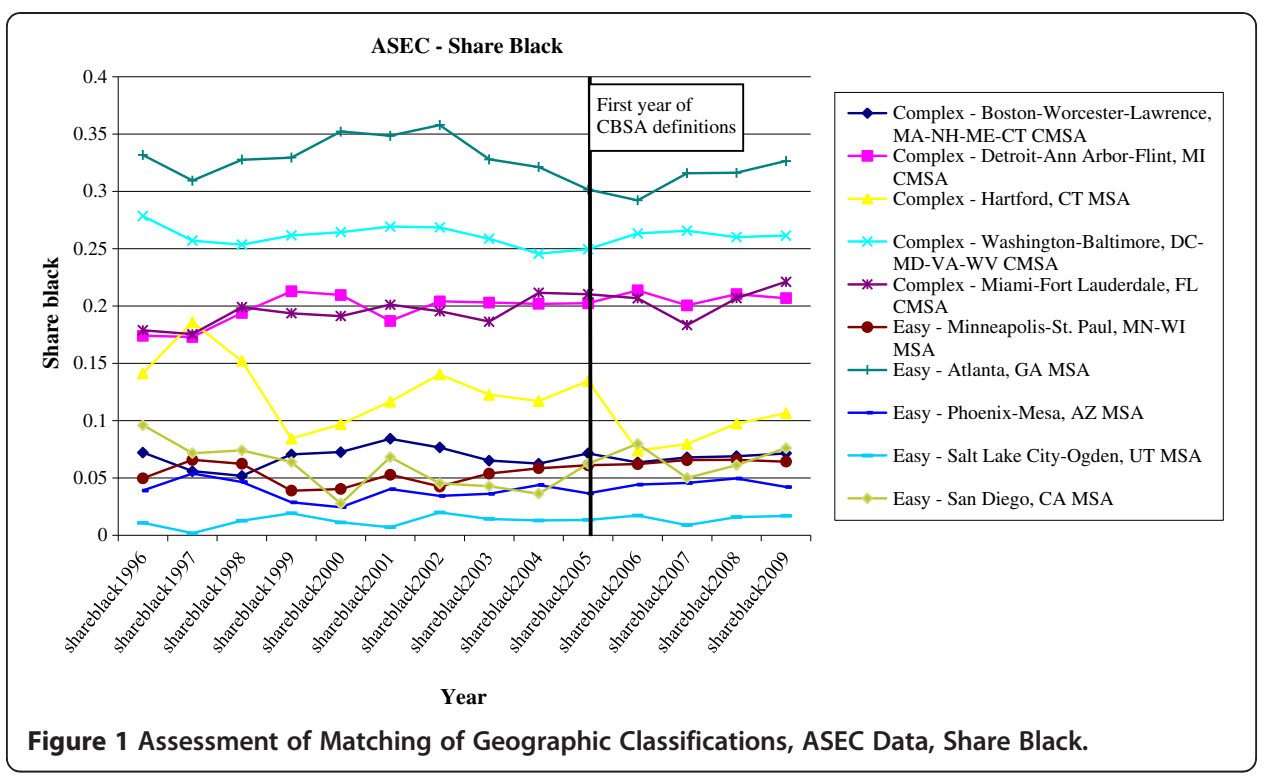

sample period 1996-2009. To have comparable analysis samples for the MORG and the ASEC data files, we required that this be met for both data files. This requirement was met by 39 of the unique MSAs/CMSAs after the geographic matching and roll-ups.

\section{Data on living wages}

Cities, rather than metropolitan areas, are the political units that adopt most living wage laws.We characterize the living wage laws prevailing in a metropolitan area based on the living wages passed by the major cities in the metropolitan area. Given the change in geographic coding, it is not entirely straightforward to define a list of cities on which to focus for the entire analysis period. Prior to the change, the classification of larger cities was based on the definition of "central cities" (Frey et al., 2004), but with the switch to CBSAs larger cities were classified as "principal cities." We needed to choose a set of cities within the 39 MSAs/CMSAs for which to code living wage laws in detail. We chose all central or principal cities subject to two criteria: a population of at least 250,000 residents according to 2000 Decennial Census data ${ }^{24}$ and if no city in the metropolitan area had at least 250,000 residents, the largest city in the metropolitan area. These criteria led to 52 cities within the 39 MSAs/CMSAs; both the cities and the MSAs/CMSAs are reported in Table 2.

For these cities,we needed historical information on living wage laws and other characteristics of the laws, such as whether they apply to recipients of financial assistance. ${ }^{25} \mathrm{We}$ first reviewed city websites for evidence of a living wage law and to identify a contact for follow-up. For cities where we initially found no evidence of a living wage law, we attempted to contact the City Clerk, City Manager, City Attorney, or Procurement/Public Works/Economic Development Officer by telephone to confirm whether the city had a living wage law at any time since 1995. If we were unable to reach the city representative by telephone, we followed up with email correspondence. At times, the first point of contact within a city directed us to another contact, at which point we would repeat the process (call, followed by email). If the representative confirmed that the city never had a 
Table 2 The 52 cities in the analysis sample, and their 39 MSAs/CMSAs

\begin{tabular}{|c|c|c|c|}
\hline MSA/CMSA & City & MSA/CMSA & City \\
\hline Albuquerque, NM MSA & Albuquerque & Milwaukee-Racine, WI CMSA & Milwaukee (1995) \\
\hline Atlanta, GA MSA & Atlanta & Minneapolis-St. Paul, MN-WI MSA & Minneapolis (1997) \\
\hline Boise City, ID MSA & Boise & Minneapolis-St. Paul, MN-WI MSA & St. Paul (2007) \\
\hline Boston-Worcester-Lawrence, MA-NH-ME-CT CMSA & Boston (1998) & New York-Northern New Jersey-Long Island, NY-NJ-CT-PA CMSA & Newark (2003) \\
\hline Charlotte-Gastonia-Rock Hill, NC-SC MSA & Charlotte & New York-Northern New Jersey-Long Island, NY-NJ-CT-PA CMSA & New York (2002) \\
\hline Chicago-Gary-Kenosha, IL-IN-WI CMSA & Chicago (1998) & Oklahoma City, OK MSA & Oklahoma City \\
\hline Cincinnati-Hamilton, OH-KY-IN CMSA & Cincinnati (2002) & Omaha, NE-IA MSA & Omaha \\
\hline Cleveland-Akron, OH CMSA & Cleveland (2000) & Orlando, FL MSA & Orlando (2003) \\
\hline Columbus, OH MSA & Columbus (2004) & Philadelphia-Wilmington-Atlantic City, PA-NJ-DE-MD CMSA & Philadelphia (2005) \\
\hline Dallas-Fort Worth, TX CMSA & Dallas & Phoenix-Mesa, AZ MSA & Phoenix \\
\hline Dallas-Fort Worth, TX CMSA & Fort Worth & Phoenix-Mesa, AZ MSA & Mesa \\
\hline Dallas-Fort Worth, TX CMSA & Arlington & Pittsburgh, PA MSA & Pittsburgh \\
\hline Denver-Boulder-Greeley, CO CMSA & Denver (2000) & Portland-Salem, OR-WA CMSA & Portland (1996) \\
\hline Denver-Boulder-Greeley, CO CMSA & Aurora & Providence-Fall River-Warwick, RI-MA MSA & Providence \\
\hline Detroit-Ann Arbor-Flint, MI CMSA & Detroit (1998) & Raleigh-Durham-Chapel Hill, NC MSA & Raleigh \\
\hline Grand Rapids-Muskegon-Holland, MI MSA & Grand Rapids & Sacramento-Yolo, CA CMSA & Sacramento (2004) \\
\hline Honolulu, HI MSA & Honolulu & Salt Lake City-Ogden, UT MSA & Salt Lake City \\
\hline Houston-Galveston-Brazoria, TX CMSA & Houston & San Diego, CA MSA & San Diego (2005) \\
\hline Kansas City, MO-KS MSA & Kansas City (2005) & San Francisco-Oakland-San Jose, CA CMSA & Oakland (1998) \\
\hline Las Vegas, NV-AZ MSA & Las Vegas & San Francisco-Oakland-San Jose, CA CMSA & San Francisco (2000) \\
\hline Los Angeles-Riverside-Orange County, CA CMSA & Los Angeles (1997) & San Francisco-Oakland-San Jose, CA CMSA & San Jose (1998) \\
\hline Los Angeles-Riverside-Orange County, CA CMSA & Santa Ana & Seattle-Tacoma-Bremerton, WA CMSA & Seattle \\
\hline
\end{tabular}


Table 2 The 52 cities in the analysis sample, and their 39 MSAs/CMSAs (Continued)

\begin{tabular}{lll}
\hline Los Angeles-Riverside-Orange County, CA CMSA & Anaheim & St. Louis, MO-IL MSA \\
Los Angeles-Riverside-Orange County, CA CMSA & Long Beach & Tampa-St. Petersburg-Clearwater, FL MSA \\
Los Angeles-Riverside-Orange County, CA CMSA & Riverside & Washington-Baltimore, DC-MD-VA-WV CMSA \\
Miami-Fort Lauderdale, FL CMSA & Miami (2006) & Washington-Baltimore, DC-MD-VA-WV CMSA \\
\hline
\end{tabular}

For cities that enacted a living wage, the year of enactment is shown in parentheses. 
living wage law, we "closed" the research on the city. If the representative indicated that there was, or had been, a living wage law, we added the city to the list for further research.

For the cities with evidence of a living wage law, we obtained as much possible information from 1995 through 2010 from the city website or directly through a city representative. Using the city website, we reviewed the current living wage law found in the city's municipal code or code of ordinances which, at times, contained a reference to the ordinance creating the code. ${ }^{26}$ The documents reviewed in the search typically generated information on the living wage history (e.g., council agendas/minutes, budget presentations, or living wage ordinance summaries), or reference forms containing the living wage rates (e.g., posters, memoranda, or living wage rate change bulletins), from which we gained additional detail. Once we established the broad picture, we used specific dates to track down the actual ordinances adopted and the living wage rates established during a given year. If necessary, we contacted city representatives by telephone or email to confirm findings or provide information that was not attainable from the city web pages.

Using this information, we coded the wage levels for the 26 cities that meet our criteria with living wages among the MSAs/PMSAs that we study, for each year and month from January 1995 through December 2009. ${ }^{27}$ We also coded whether or not the living wage law applies to business assistance recipients. ${ }^{28}$ The new information on living wage laws emphasizes the potential value of updating the research on living wages. Of these 26 cities, 14 had enacted living wages prior to 2002, and 12 did so afterwards. Table 2 shows the year of enactment of living wages for the cities in our analysis that enacted them. Thus, between the cities with new living wage laws, plus the additional observations on cities that passed them earlier and increased the level of the living wage subsequently, there is a good deal more information on the effects of living wages - and of course information that is more contemporary.

\section{Results: wage and employment effects}

The first two columns of Table 3 repeat the basic estimates, from Adams and Neumark (2005a), of the effects of living wages on wages of workers in the bottom decile of the wage distribution, and the bottom decile of the skill (predicted wage) distribution; these estimates were discussed in Section II. The data cover all residents of MSAs and PMSAs identified in the CPS ORG data in the 1996-2002 period, in city-month cells with 25 or more observations. The key living wage variable in the model, for which estimates are reported in the table, is the log of the maximum of the living wage or the minimum wage prevailing in the city, lagged 12 months. ${ }^{29}$ The maximum of the two is used to capture the effective wage floor, and the 12-month lag is used based on evidence that the effects of living wages do not occur instantly but emerge over about one year. ${ }^{30}$ The regressions include controls for city, year, month, minimum wages, and other individual-level controls. The specification also includes differential linear time trends for cities passing or not passing living wage laws, or passing different types of living wage laws. The first row reports the estimates from a single regression on the living wage variable, without distinguishing the types of living wage laws. In the second and third rows, instead, each column reports results from a specification that distinguishes between contractor-only and business assistance living wage laws (by interacting the living wage variable with dummy variables for these types of laws, constructed to be mutually exclusive). 
Table 3 Estimated effects of living wages on log wages and employment, lowest decile of wage distribution or predicted wage distribution (for employment), living wages defined at MSA/PMSA level, prior estimates and re-estimations for 1996-2002

\begin{tabular}{|c|c|c|c|c|c|c|c|c|c|}
\hline & \multicolumn{2}{|c|}{ Previous Estimates } & \multicolumn{2}{|c|}{$\begin{array}{l}\text { Restricted to } 79 \mathrm{MSAs} / \\
\text { PMSAs in CMSAs }\end{array}$} & \multicolumn{2}{|c|}{$\begin{array}{l}\text { Restricted to } 79 \mathrm{MSAs} / \mathrm{PMSAs} \text {, } \\
\text { corrected living wage laws }\end{array}$} & \multicolumn{2}{|c|}{$\begin{array}{l}\text { Same as columns (5) and (6), } \\
\text { with city-specific trends }\end{array}$} & \multirow{2}{*}{$\begin{array}{l}\text { Larger sample of MS } \\
\text { (9) }\end{array}$} \\
\hline & (1) & $(2)$ & (3) & (4) & (5) & (6) & (7) & $(8)$ & \\
\hline Dependent variable: & Log wages & Employment & Log wages & Employment & Log wages & Employment & Log wages & Employment & Employmen \\
\hline \multicolumn{10}{|l|}{ Specification 1} \\
\hline \multirow[t]{2}{*}{ Log living wage, lagged 12 months } & 0.040 & $-0.053^{* *}$ & $0.046^{*}$ & $-0.047^{* *}$ & $0.043^{*}$ & $-0.066^{* *}$ & 0.034 & $-0.061^{* *}$ & $-0.061^{* *}$ \\
\hline & $(0.030)$ & $(0.020)$ & $(0.024)$ & $(0.019)$ & $(0.026)$ & $(0.020)$ & $(0.031)$ & $(0.019)$ & $(0.019)$ \\
\hline \multicolumn{10}{|l|}{ Specification 2} \\
\hline \multicolumn{10}{|l|}{ Business assistance living wage laws: } \\
\hline \multirow[t]{2}{*}{ Log living wage, lagged 12 months } & $0.067^{*}$ & $-0.076^{* *}$ & $0.071^{* *}$ & $-0.067^{* *}$ & $0.080^{* *}$ & $-0.069^{* *}$ & $0.070^{*}$ & $-0.073^{* *}$ & $-0.074^{* *}$ \\
\hline & $(0.039)$ & $(0.018)$ & $(0.028)$ & $(0.020)$ & $(0.030)$ & $(0.020)$ & $(0.037)$ & $(0.021)$ & $(0.021)$ \\
\hline \multicolumn{10}{|l|}{ Contractor-only living wage laws: } \\
\hline \multirow[t]{2}{*}{ Log living wage, lagged 12 months } & -0.006 & -0.027 & 0.005 & -0.017 & -0.007 & $-0.070^{* *}$ & -0.016 & -0.043 & -0.043 \\
\hline & $(0.037)$ & $(0.033)$ & $(0.035)$ & $(0.031)$ & $(0.028)$ & $(0.035)$ & $(0.040)$ & $(0.032)$ & $(0.032)$ \\
\hline N & 46,374 & 116,466 & 44,588 & 90,695 & 44,588 & 90,695 & 44,588 & 90,695 & 92,091 \\
\hline
\end{tabular}

The estimates in columns (1) and (2) are from Adams and Neumark (2005a, Tables 2 and 4). The data on labor market outcomes and other worker-related characteristics come from the Current Population Survey (CPS) monthly Outgoing Rotation Group files (ORGs/MORGs), from January 1996 through December 2002. Only observations on city-month or city-year cells with 25 or more observations are retained. The living wage variable is the maximum of the log of the living or minimum wage, and so equals the minimum wage when there is no living wage. The regressions include controls for city, year, month, log minimum wages, and other individual-level controls. All specifications also allow differential linear time trends for cities passing or not passing living wage laws, or passing different types of laws, except columns (7) and (8). The entries in the first row are from a specification with a single living wage variable, and the entries in the second and third rows are from a specification that interacts the living wage variable with dummy variables for the type of living wage. The MSAs/PMSAs beginning in columns (3)-(4) are the MSAs and PMSAs that constitute the 39 CMSAs that we can track for the entire sample period and that meet the data sufficiency requirement (50 living wage. The MSAS/MSAs beginning in columns (3)-(4) are th MSAs and PMSAs that constitute the 39 CMSAs that we can track for the entire sample period and that meet the data suficiency requirement (50 valid wage observations per MSARMSA and month). The list of the 79 MSAS/PMSAs used in columns (3)-(6) is available from the authors upon request. There are $86 \mathrm{MSA}$ (PMSAs in column ( impose the same data sufficiency requireme on the employment and wage samples. Estimates are weighted by individual sample weights. " (") superscipt indicates estimate is statistically significant at fivepercent (ten-percent) level. Reported standard errors are robust to nonindependence (and heteroscedasticity) within city cells (clustered by city). 
The wage equation is a log-log specification, so the coefficients are elasticities. For example, the upper-left estimate means that a $100 \%$ increase in the living wage (e.g., from a $\$ 5$ minimum wage to a $\$ 10$ living wage) would increase wages in the bottom decile of the wage distribution by $0.04 \log$ points, or approximately $4 \%$. The coefficients from the employment regressions measure the change in the probability of employment in response to a one-unit increase in the log living wage (or a 100\% increase).

For the first specification, the estimates in columns (1) and (2) indicate that living wages lead to higher wages and lower employment; only the estimated employment effect is statistically significant. In the second specification, business assistance living wage laws have significant positive effects on wages, and significant negative effects on employment, whereas the effects of the narrower contractor-only laws are smaller and insignificant (and the wage effect is very close to zero). The magnitudes imply that a $100 \%$ business assistance living wage increase boosts wages in the bottom decile of the distribution by $6.7 \%$, and reduces employment in the bottom decile by 7.6 percentage points.

The remainder of Table 3 shows the consequences of some changes to the sample necessitated by the aggregation of MSAs/PMSAs to MSAs/CMSAs, and of other changes to the data or specification. First, columns (3) and (4) report estimates using the exact same data and specifications, but restricting attention to the MSAs/PMSAs that are aggregated to MSAs/CMSAs in what follows. This entails very small reductions in the sample size, as only 12 very small MSAs/PMSAs that were included in the original analysis are dropped. For the wage analysis, 79 MSAs/PMSAs meet this criterion and other sample size restrictions. More MSAs/PMSAs meet the sample size restrictions for the analysis of employment, because the samples for these outcomes are larger. However, we report most results for the consistent set of MSAs/PMSAs. We also report key results for the largest possible samples of MSAs/PMSAs within these MSAs/CMSAs, on the argument that these give us the most reliable estimates for each outcome. The changes in the estimates shown in columns (3) and (4) are inconsequential.

Columns (5) and (6) incorporate some slight changes in the living wage data based on the new research on the history of living wage laws. Most of the estimates are essentially unchanged, with the exception of the employment effect for contractor-only living wage laws, which is now the same magnitude as for business assistance laws and statistically significant. Columns (7) and (8) report specifications in which less-restrictive linear trends now, simply city-specific linear trends - are substituted for the differential linear time trends for cities passing or not passing living wage laws, or passing different types of laws. For business assistance living wage laws, which are our main focus, this change has little bearing on the estimates. Again, though, the results for contractor-only laws are more sensitive (and, consequently, so are the results for living wages overall). In particular, there is now no evidence of a statistically significant positive wage effect for living wages overall, or of significant (positive) wage effects or (negative) employment effects for contractoronly laws. As reported in column (9), the employment effects are robust to including an additional seven MSAs/PMSAs that meet the data sufficiency criterion for employment but not wages. The conclusion from these estimates is still that business assistance living wage laws lead to positive wage effects and negative employment effects, both of which are statistically significant. The estimates with city-specific trends become our "baseline" estimates for purposes of comparison going forward. ${ }^{31}$ 
Table 4 explores the consequences of extending the data through 2009, which requires the aggregation to MSAs/CMSAs. Now the key variable in the model, for which estimates are reported in the table, is the log of the maximum of the minimum wage or the weighted living wage (weighted by population share of the MSAs or PMSAs in the MSA/CMSA), lagged 12 months as before. This weighted living wage variable is calculated by multiplying the living wage in an MSA/PMSA by the population share of that MSA/PMSA in the total MSA/CMSA population living in MSAs or PMSAs (based on 2000 Census data), and summing the weighted living wages across all MSA/PMSAs in the MSA/CMSA.

As columns (3) and (4) show, once we aggregate and extend the data, the evidence changes relative to the baseline estimates (columns (1) and (2)). For wages, the estimated effects of the overall living wage and the two separate living wage variables are all positive but statistically insignificant, and the estimate for business assistance living wage laws which was larger and statistically significant in the previous analyses - declines. For the employment effects, although all of the estimates are negative, none is large compared to the overall and business assistance living wage effects estimated earlier, and the estimate for business assistance living wages, which should have the highest coverage, is not significant.

To explore the consequences of the aggregation of MSAs and PMSAs to MSAs/CMSAs necessitated by the changes in the CPS data, in columns (5) and (6) we keep everything the same as in columns (1) and (2) - in particular, using the data only through 2002 - and the only change we make is to do this aggregation. The estimates also change substantially relative to columns (1) and (2) and are not very different from those when we extend the data through 2009. This illustrates that it is the aggregation that changes the estimates, rather than extension of the sample period.

The aggregation to MSAs/CMSAs turns out to pose a severe empirical problem for a very simple reason: it is difficult to measure living wages at the MSA/CMSA level because of many instances in which MSAs or PMSAs within an MSA/CMSA adopt living wages at different times (and also at different levels, although the differences in timing are the more serious issue). Table 5 illustrates the problem, for the case of Boston. ${ }^{32}$ Boston passed a living wage in 1998, while the other MSAs and PMSAs in the CMSA did not. For the years in the sample period through 2002 (when the original analysis ended), somewhat under half the observations in the CMSA are outside of the Boston PMSA. In the original analysis through 2002, the Boston living wage was assigned only to the Boston PMSA. However, with the change in geographic classification, the other five MSAs/PMSAs were aggregated with the Boston PMSA, resulting in the living wage being assigned to all six of them beginning in July 1998, when the Boston living wage was implemented. Table 5 shows that in 1997 (and the same is true earlier) when there was no living wage in Boston, there is no measurement problem. The living wage takes effect midway through 1998, so the percentage of observations with the wrong living wage (and the average magnitude of the error) is fairly small in that year. In 1999 (and subsequently), the error rate and magnitude of the error becomes considerably larger.

Table 6 shows a similar problem for the aggregated San Francisco-Oakland-San Jose CMSA. In this case, the adoption of living wages differs, with each of the three major constituent MSAs/PMSAs adopting living wage laws at different times. Nonetheless, the same severe measurement problem emerges. One difference in this case, though, is that the error decreases over time, as the major MSAs/PMSAs each adopt a living wage. 
Table 4 Updated estimates of effects of living wages on log wages and employment, lowest decile of wage distribution or predicted wage distribution (for employment)

\begin{tabular}{|c|c|c|c|c|c|c|c|c|}
\hline & \multicolumn{2}{|c|}{$\begin{array}{l}\text { "Baseline" estimates, Table 3, } \\
\text { columns (7) and (8), 1996-2002 }\end{array}$} & \multicolumn{2}{|c|}{$\begin{array}{l}\text { Living wage variables aggregated to } \\
\text { CMSA level, 1996-2009 }\end{array}$} & \multicolumn{2}{|c|}{$\begin{array}{l}\text { Living wage variables aggregated to } \\
\text { CMSA level, 1996-2002 }\end{array}$} & \multicolumn{2}{|c|}{$\begin{array}{l}\text { Living wages defined at MSA } \\
\text { PMSA level, 1996-2004 }\end{array}$} \\
\hline & (1) & (2) & (3) & (4) & (5) & (6) & (7) & (8) \\
\hline Dependent variable: & Log wages & Employment & Log wages & Employment & Log wages & Employment & Log wages & Employment \\
\hline \multicolumn{9}{|l|}{ Specification 1} \\
\hline \multirow[t]{2}{*}{ Log living wage, lagged 12 months } & 0.034 & $-0.061^{* *}$ & 0.026 & $-0.019^{* *}$ & 0.009 & $-0.039^{*}$ & 0.037 & $-0.052^{* *}$ \\
\hline & $(0.031)$ & $(0.019)$ & $(0.019)$ & $(0.009)$ & $(0.036)$ & $(0.021)$ & $(0.034)$ & $(0.017)$ \\
\hline \multicolumn{9}{|l|}{ Specification 2} \\
\hline \multicolumn{9}{|l|}{ Business assistance living wage laws: } \\
\hline \multirow[t]{2}{*}{ Log living wage, lagged 12 months } & $0.070^{*}$ & $-0.073^{* *}$ & 0.021 & -0.005 & 0.025 & -0.026 & 0.051 & $-0.055^{* *}$ \\
\hline & $(0.037)$ & $(0.021)$ & $(0.023)$ & $(0.012)$ & $(0.042)$ & $(0.026)$ & $(0.041)$ & $(0.023)$ \\
\hline \multicolumn{9}{|l|}{ Contractor-only living wage laws: } \\
\hline \multirow[t]{2}{*}{ Log living wage, lagged 12 months } & -0.016 & -0.043 & 0.022 & $-0.029^{* *}$ & -0.052 & -0.053 & 0.020 & $-0.048^{* *}$ \\
\hline & $(0.040)$ & $(0.032)$ & $(0.027)$ & $(0.014)$ & $(0.057)$ & $(0.035)$ & $(0.056)$ & $(0.023)$ \\
\hline $\mathrm{N}$ & 44,588 & 90,695 & 86,614 & 188,769 & 44,588 & 90,695 & 53,038 & 109,725 \\
\hline
\end{tabular}

nonindependence (and heteroscedasticity) within city cells (clustered by city). 
Table 5 Living wages and aggregation errors, boston CMSA and MSAs/PMSAs, years surrounding enactment of Boston living wage

\begin{tabular}{|c|c|c|c|c|c|}
\hline Year & MSA name & CMSA living wage & MSA/PMSA living wage & $\%$ obs. incorrect & Avg. magnitude of difference \\
\hline 1997 & Boston, MA-NH PMSA (New Hampshire portion not identified) & 5.25 & 5.25 & $0 \%$ & $0 \%$ \\
\hline 1997 & Lowell, MA-NH PMSA (New Hampshire portion not identified) & 5.25 & 5.25 & $0 \%$ & $0 \%$ \\
\hline 1997 & Manchester, NH PMSA & 4.89 & 4.89 & $0 \%$ & $0 \%$ \\
\hline 1997 & Nashua, NH PMSA & 4.88 & 4.88 & $0 \%$ & $0 \%$ \\
\hline 1997 & Portsmouth-Rochester, NH-ME PMSA (Maine portion not identified) & 4.89 & 4.89 & $0 \%$ & $0 \%$ \\
\hline 1997 & Worcester, MA-CT PMSA (Connecticut portion suppressed) & 5.25 & 5.25 & $0 \%$ & $0 \%$ \\
\hline 1998 & Boston, MA-NH PMSA (New Hampshire portion not identified) & 6.74 & 6.74 & $0 \%$ & $0 \%$ \\
\hline 1998 & Lowell, MA-NH PMSA (New Hampshire portion not identified) & 6.62 & 5.25 & $46 \%$ & $26 \%$ \\
\hline 1998 & Manchester, NH PMSA & 6.63 & 5.15 & $48 \%$ & $29 \%$ \\
\hline 1998 & Nashua, NH PMSA & 6.69 & 5.15 & $50 \%$ & $30 \%$ \\
\hline 1998 & Portsmouth-Rochester, NH-ME PMSA (Maine portion not identified) & 6.84 & 5.15 & $55 \%$ & $33 \%$ \\
\hline 1998 & Worcester, MA-CT PMSA (Connecticut portion suppressed) & 6.68 & 5.25 & $48 \%$ & $27 \%$ \\
\hline 1999 & Boston, MA-NH PMSA (New Hampshire portion not identified) & 8.32 & 8.32 & $0 \%$ & $0 \%$ \\
\hline 1999 & Lowell, MA-NH PMSA (New Hampshire portion not identified) & 8.32 & 5.25 & $100 \%$ & $58 \%$ \\
\hline 1999 & Manchester, NH PMSA & 8.32 & 5.15 & $100 \%$ & $61 \%$ \\
\hline 1999 & Nashua, NH PMSA & 8.32 & 5.15 & $100 \%$ & $62 \%$ \\
\hline 1999 & Portsmouth-Rochester, NH-ME PMSA (Maine portion not identified) & 8.32 & 5.15 & $100 \%$ & $62 \%$ \\
\hline 1999 & Worcester, MA-CT PMSA (Connecticut portion suppressed) & 8.31 & 5.25 & $100 \%$ & $58 \%$ \\
\hline
\end{tabular}

Boston's living wage was adopted in 1998. The living wage variables are averaged over months in a year. The MSA/PMSA living wage sometimes shows small deviations before there is a living wage because the table reports the average minimum wage (or living wage, if there is one), the state minimum wage can change mid-year, and the sample proportions in different months can vary across areas. 
Table 6 Living wages and aggregation errors, San Francisco-Oakland-San Jose CMSA and PMSAs, years surrounding enactment of living wages in PMSAs

\begin{tabular}{|c|c|c|c|c|c|}
\hline Year & MSA name & CMSA living wage & MSA/PMSA living wage & $\%$ obs. incorrect & Avg. magnitude of difference \\
\hline 1997 & Oakland, CA PMSA & 5.01 & 5.01 & $0 \%$ & $0 \%$ \\
\hline 1997 & San Francisco, CA PMSA & 5.01 & 5.01 & $0 \%$ & $0 \%$ \\
\hline 1997 & San Jose, CA PMSA & 5.01 & 5.01 & $0 \%$ & $0 \%$ \\
\hline 1997 & Santa Rosa, CA PMSA & 4.98 & 4.98 & $0 \%$ & $0 \%$ \\
\hline 1997 & Vallejo-Fairfield-Napa, CA PMSA & 5.00 & 5.00 & $0 \%$ & $0 \%$ \\
\hline 1998 & Oakland, CA PMSA & 6.25 & 7.34 & $75 \%$ & $-14 \%$ \\
\hline 1998 & San Francisco, CA PMSA & 6.21 & 5.64 & $15 \%$ & $10 \%$ \\
\hline 1998 & San Jose, CA PMSA & 6.13 & 6.13 & $0 \%$ & $0 \%$ \\
\hline 1998 & Santa Rosa, CA PMSA & 5.93 & 5.61 & $8 \%$ & $6 \%$ \\
\hline 1998 & Vallejo-Fairfield-Napa, CA PMSA & 6.40 & 5.67 & $20 \%$ & $13 \%$ \\
\hline 1999 & Oakland, CA PMSA & 9.50 & 8.11 & $100 \%$ & $17 \%$ \\
\hline 1999 & San Francisco, CA PMSA & 9.50 & 5.75 & $100 \%$ & $65 \%$ \\
\hline 1999 & San Jose, CA PMSA & 9.50 & 9.50 & $0 \%$ & $0 \%$ \\
\hline 1999 & Santa Rosa, CA PMSA & 9.50 & 5.75 & $100 \%$ & $65 \%$ \\
\hline 1999 & Vallejo-Fairfield-Napa, CA PMSA & 9.50 & 5.75 & $100 \%$ & $65 \%$ \\
\hline 2000 & Oakland, CA PMSA & 9.80 & 8.30 & $100 \%$ & $18 \%$ \\
\hline 2000 & San Francisco, CA PMSA & 9.79 & 6.77 & $100 \%$ & $50 \%$ \\
\hline 2000 & San Jose, CA PMSA & 9.81 & 9.81 & $0 \%$ & $0 \%$ \\
\hline 2000 & Santa Rosa, CA PMSA & 9.81 & 5.75 & $100 \%$ & $71 \%$ \\
\hline 2000 & Vallejo-Fairfield-Napa, CA PMSA & 9.85 & 5.75 & $100 \%$ & $71 \%$ \\
\hline 2001 & Oakland, CA PMSA & 10.10 & 8.53 & $100 \%$ & $18 \%$ \\
\hline 2001 & San Francisco, CA PMSA & 10.10 & 9.00 & $100 \%$ & $12 \%$ \\
\hline 2001 & San Jose, CA PMSA & 10.10 & 10.10 & $0 \%$ & $0 \%$ \\
\hline 2001 & Santa Rosa, CA PMSA & 10.10 & 6.25 & $100 \%$ & $62 \%$ \\
\hline
\end{tabular}


Table 6 Living wages and aggregation errors, San Francisco-Oakland-San Jose CMSA and PMSAs, years surrounding enactment of living wages in PMSAs

(Continued)

\begin{tabular}{|c|c|c|c|c|c|}
\hline 2001 & Vallejo-Fairfield-Napa, CA PMSA & 10.10 & 6.25 & $100 \%$ & $62 \%$ \\
\hline 2002 & Oakland, CA PMSA & 10.10 & 8.69 & $100 \%$ & $16 \%$ \\
\hline 2002 & San Francisco, CA PMSA & 10.10 & 10.00 & $100 \%$ & $1 \%$ \\
\hline 2002 & San Jose, CA PMSA & 10.10 & 10.10 & $0 \%$ & $0 \%$ \\
\hline 2002 & Santa Rosa, CA PMSA & 10.10 & 6.75 & $100 \%$ & $50 \%$ \\
\hline 2002 & Vallejo-Fairfield-Napa, CA PMSA & 10.10 & 6.75 & $100 \%$ & $50 \%$ \\
\hline
\end{tabular}

The Oakland and San Jose living wages were adopted in 1998, and San Francisco's in 2000. The living wage variables are averaged over months in a year. The MSA/PMSA living wage sometimes shows small deviations before there is a living wage because the table reports the average minimum wage (or living wage, if there is one), the state minimum wage can change mid-year, and the sample proportions in different months can before there is a livir vary across areas. 
There is a similar aggregation problem for other cities for which MSAs/CMSAs include MSAs/PMSAs with different living wages. There are only 20 MSAs/CMSAs that do not suffer from either problem, and only five of these have living wage laws; hence we could not reliably estimate living wage effects using this subset of observations.

As a consequence of this aggregation problem, the best alternative is likely to revert to the specification at the MSA/PMSA level, and to use as long a sample period as possible prior to the change in geographic coding. For the analysis of wages and employment, this implies extending the sample period through 2004, which unfortunately does not provide as much "updating" as we would like. Nonetheless, this does give us information on an additional four cities that passed living wage laws in 2003 or 2004 (Columbus, OH, Newark, NJ, Orlando, FL, and Sacramento, CA). Results are reported in the final two columns of Table 4. There are some changes relative to the baseline estimates in columns (1)-(2). For the living wage variable overall, and the business assistance living wage variable, the estimated wage effects are smaller, and the wage effect for business assistance living wage laws is no longer statistically significant, although the estimated coefficient still implies a sizable effect: a 100\% living wage increase boosts wages in the bottom decile of the wage distribution by $5.1 \%$. For employment effects, in contrast, the evidence is somewhat stronger. There is still evidence of a statistically significant negative effect of business assistance living wage laws on employment of less-skilled individuals and of living wage laws overall. But now the estimate is similar (albeit a bit smaller), and statistically significant, for contractor-only living wages as well. ${ }^{33}$

We also estimated these specifications for different ranges of the wage and skill distribution. This is of interest for two reasons. First, as confirmation that we are truly detecting effects of living wages on low-wage, low-skilled workers in the results reported above, we should clearly not find evidence of positive wage and negative employment effects higher up in the wage or skill distribution. Second, a living wage can generate demand shifts toward higher-skilled workers, increasing their wages and employment (e.g., Fairris and Bujanda, 2008). And as Adams and Neumark (2005a) showed, many poor families have workers who earn relatively low wages or have relatively low skills but are not necessarily in the bottom $10^{\text {th }}$ of the distribution. ${ }^{34}$ Thus, policies that end up helping workers who are in a higher part of the wage distribution can reduce poverty. ${ }^{35}$

As reported in Table 7, we found little evidence of effects higher up in the wage or skill distribution. The wage effects were small and centered on zero, and not statistically significant. The estimated employment effects were also small and statistically insignificant, although more uniformly negative. These results suggest that effects of living wages on the distribution of family incomes stem mainly from the effects of living wages on the lowest-wage and lowest-skilled workers. Moreover, the absence of any evidence higher up in the wage or skill distribution paralleling that for the lowest-wage, lowest-skill workers makes it less likely that our results for the latter groups reflect spurious effects of changes in economic conditions correlated with living wages. That is, these results serve as a placebo test.

Based on our updated evidence, there is now stronger evidence of disemployment effects, and it is not only limited to business assistance living wage laws. And there is weaker evidence of wage effects. Two points related to these findings merit discussion. First, in the earlier work, the stronger evidence of effects of business assistance living wage laws was attributed to the likely higher coverage of these laws as well as other features of those laws, although the evidence was not decisive (see Adams and Neumark, 
Table 7 Estimated effects of living wages on log wages and employment in other ranges of the wage or predicted wage distribution (for employment) living wages defined at MSA/PMSA level, updated, 1996-2004

\begin{tabular}{|c|c|c|c|c|c|c|}
\hline & \multicolumn{2}{|c|}{$0^{\text {th }}-10^{\text {th }}$ percentile } & \multicolumn{2}{|c|}{$10^{\text {th }}-25^{\text {th }}$ percentile } & \multicolumn{2}{|c|}{$25^{\text {th }}-50^{\text {th }}$ percentile } \\
\hline & (1) & (2) & (3) & (4) & (5) & (6) \\
\hline Dependent variable: & Wages & Employment & Wages & Employment & Wages & Employment \\
\hline \multicolumn{7}{|l|}{ Specification 1} \\
\hline \multirow[t]{2}{*}{ Log living wage, lagged 12 months } & 0.037 & $-0.052^{* *}$ & -0.013 & 0.000 & -0.013 & -0.003 \\
\hline & $(0.034)$ & $(0.017)$ & $(0.019)$ & $(0.024)$ & $(0.021)$ & $(0.017)$ \\
\hline \multicolumn{7}{|l|}{ Specification 2} \\
\hline \multicolumn{7}{|l|}{ Business assistance living wage laws: } \\
\hline \multirow[t]{2}{*}{ Log living wage, lagged 12 months } & 0.051 & $-0.055^{* *}$ & -0.018 & 0.017 & -0.029 & 0.013 \\
\hline & $(0.041)$ & $(0.023)$ & $(0.028)$ & $(0.022)$ & $(0.030)$ & $(0.011)$ \\
\hline \multicolumn{7}{|l|}{ Contractor-only living wage laws: } \\
\hline \multirow[t]{2}{*}{ Log living wage, lagged 12 months } & 0.020 & $-0.048^{* *}$ & -0.006 & -0.019 & 0.006 & -0.022 \\
\hline & $(0.056)$ & $(0.023)$ & $(0.025)$ & $(0.045)$ & $(0.025)$ & $(0.033)$ \\
\hline $\mathrm{N}$ & 53,038 & 109,725 & 65,812 & 158,308 & 109,064 & 263,897 \\
\hline
\end{tabular}

See notes to Table 3. ${ }^{* * *^{\prime}}\left({ }^{(* \prime}\right)$ superscript indicates estimate is statistically significant at five-percent (ten-percent) level. All specifications have city-specific trends. Columns (1)-(2) include observations less than or equal to the $10^{\text {th }}$ percentile; columns (3)-(4) from greater than the $10^{\text {th }}$ to less than or equal to the $25^{\text {th }}$; and columns (5)-(6) from greater than the $25^{\text {th }}$ to less than or equal to the $50^{\text {th }}$. Note that the sample sizes do not change in close proportions to the percentage of observations in each range based solely on the percentiles. This occurs because the percentiles are calculated for fairly small samples in many instances (since they are change in close proportions to the percentage of observations in each range based solely on the percentiles. This occurs because the percentiles are calculated for fairly small samples in many instances (since they are
computed for city-month cells), so there are often large numbers of ties in the rankings of observations. We define the samples in the different columns as explained earlier in the note, so in some cases the share of computed for city-month cells), so there are often large numbers of ties in the rankings of observations. We define the samples in the different columns as explained earlier in the note, so in some cases the share of
observations in a range can substantially exceed or fall short of the strict definition. (For example, if there are many observations on either side of the $10^{\text {th }}$ percentile, but the $25^{\text {th }}$ percentile is higher, then more than observations in a range can substantially exceed or fall short of the strict definition. (For example, if there are many observations on either side of the $10^{\text {tin }}$ percentile, but the 25 (a)
one-tenth of the observations will be in the lower decile.) Reported standard errors are robust to nonindependence (and heteroscedasticity) within city cells (clustered by city). 
2005a). There is no indication one way or another that coverage of contractor-only laws has increased because of some inherent broadening of the laws. However, the laws may now have stronger effects, because in the earlier years of living wage laws, there may have been a greater preponderance of non-renewed contracts that were not covered. It is true that the business assistance provisions also often applied only to new assistance. But as discussed earlier, these business assistance provisions may have broader effects.

Second, the early wave of research on living wages was based on relatively few periods covering a fairly small number of cities. As a result, the results were described as somewhat provisional, requiring more data and more analysis for confirmation..$^{36}$ Consequently, it is not surprising that there are some changes in the answers relative to the earlier research, although in general most of the qualitative results persist, including the results for poverty discussed below. At the same time, the above discussion regarding the problems of aggregating geographic data on U.S. cities, using CPS data, indicates that we have been unable to add a large number of years of data with reliable measurement of living wages.

\section{Results: Effects on low-income families}

We next report estimates of the effects of living wages on family income (poverty) and on government benefits to families. These estimates tell us how the various and possibly complicated wage and employment (and hours) effects on individuals ultimately affect families. Table 8 focuses on whether living wages reduce the probability that families are poor. These models are estimated for the full sample, not the lower decile of the wage or skill distribution (or other ranges). Column (1) repeats the estimates from Adams and Neumark (2005a). The estimates are negative for living wages generally and for business assistance living wages (although the point estimate is larger for contractor-only living wages). To interpret the estimates, the -0.024 estimate for business assistance living wage laws, for example, implies that a $100 \%$ increase in this type of living wage reduces the poverty rate by 2.4 percentage points. Columns (2) and (3) report the results for the restricted sample (79 cities), and then with city-specific trends. These results are consistent with business assistance living wage laws being the only types of living wage laws that reduce poverty.

We next return to the issue of aggregation of urban areas into MSAs/CMSAs, which is necessary to update the results fully. Doing the aggregation without changing the sample period (column (4)) leads to estimated effects - in the direction of reducing poverty - that are a bit larger. In columns (5)-(6), we show the aggregated estimates through 2009, and then the disaggregated estimates (which we think are most reliable) through $2003,{ }^{37}$ the last year for which the disaggregated data are available. The basic qualitative conclusion that business assistance living wage laws reduce urban poverty - is robust across all of these estimates. However, the estimates through 2003, without aggregating, no longer show a statistically significant effect of business assistance living wage laws in reducing poverty. Nonetheless, we do not want to dismiss the aggregated results, which show a statistically significant effect of business assistance living wages in reducing poverty. ${ }^{38}$ Moreover, in both columns (5) and (6) we no longer - relative to the earlier estimates reported in column (1) - find any effect of contractor-only living wage laws on poverty.

Finally, we examined information on income-support and other assistance programs. Given that many income-support programs require low family income to qualify, or tie benefits to income, we might expect the beneficial effects of living wages to be more 
Table 8 Estimated effects of living wages on probability that family is poor, prior estimates, re-estimations, and updated estimates

\begin{tabular}{|c|c|c|c|c|c|c|}
\hline & \multirow{2}{*}{\begin{tabular}{|c|}
$1995-2001$ \\
$\begin{array}{c}\text { Previous estimates, } \\
\text { restricted trends }\end{array}$
\end{tabular}} & \multicolumn{2}{|c|}{$\begin{array}{l}\text { Restricted to } 79 \text { MSAs/ } \\
\text { PMSAs, corrected living } \\
\text { wage laws, 1995-2001 }\end{array}$} & \multirow{2}{*}{$\begin{array}{l}\text { Living wage variables aggregated to } \\
\text { CMSA level, 1995-2001 } \\
\text { City-specific trends }\end{array}$} & \multirow{2}{*}{$\begin{array}{l}\text { Living wage variables aggregated to } \\
\text { CMSA level, } 1995-2009 \\
\text { City-specific trends }\end{array}$} & \multirow{2}{*}{$\begin{array}{c}\text { Column (3) updated } \\
1995-2003 \\
\text { City-specific trends }\end{array}$} \\
\hline & & $\begin{array}{l}\text { Restricted } \\
\text { trends }\end{array}$ & $\begin{array}{l}\text { City-specific } \\
\text { trends }\end{array}$ & & & \\
\hline & (1) & (2) & (3) & (4) & (5) & (6) \\
\hline Sample mean & & 0.179 & 0.179 & 0.178 & 0.182 & 0.181 \\
\hline \multicolumn{7}{|l|}{ Specification 1} \\
\hline \multirow{2}{*}{$\begin{array}{l}\text { Log living wage, lagged } \\
12 \text { months }\end{array}$} & $-0.035^{* *}$ & -0.024 & -0.019 & $-0.045^{* *}$ & -0.001 & -0.008 \\
\hline & $(0.013)$ & $(0.017)$ & $(0.016)$ & $(0.017)$ & $(0.009)$ & $(0.016)$ \\
\hline \multicolumn{7}{|l|}{ Speciification 2} \\
\hline \multicolumn{7}{|c|}{ Business assistance living wage laws: } \\
\hline \multirow{2}{*}{$\begin{array}{l}\text { Log living wage, lagged } \\
12 \text { months }\end{array}$} & $-0.024^{*}$ & -0.027 & $-0.041^{*}$ & $-0.069^{* *}$ & $-0.024^{* *}$ & -0.035 \\
\hline & $(0.013)$ & $(0.022)$ & $(0.021)$ & $(0.022)$ & $(0.012)$ & $(0.022)$ \\
\hline \multicolumn{7}{|c|}{ Contractor-only living wage laws: } \\
\hline \multirow{2}{*}{$\begin{array}{l}\text { Log living wage, lagged } \\
12 \text { months }\end{array}$} & -0.038 & -0.012 & 0.012 & -0.003 & 0.017 & 0.021 \\
\hline & $(0.025)$ & $(0.024)$ & $(0.023)$ & $(0.026)$ & $(0.011)$ & $(0.020)$ \\
\hline $\mathrm{N}$ & 142,421 & 115,818 & 115,818 & 117,658 & 308,008 & 157,048 \\
\hline
\end{tabular}

See notes to Table 3. The March ASEC files are used for these estimates. Poverty is defined in terms of total income. The estimates in column (1) are from Adams and Neumark (2005a, Table 5). The regressions include controls for city, year, and minimum wages. Estimates are weighted by family sample weights. ${ }^{\prime * * \prime}{ }^{\left(*{ }^{\prime \prime}\right)}$ superscript indicates estimate is statistically significant at five-percent (ten-percent) level. Reported standard errors are robust to nonindependence (and heteroscedasticity) within city cells (clustered by city). 
limited than the increase in earnings, because rising earnings reduce eligibility for benefits or affect the amounts for which families are eligible from social programs such as Medicaid, S-CHIP, Food Stamps, housing assistance, and the Earned Income Tax Credit. ${ }^{39}$ The implication is that families that see earnings rise because of a living wage law would also receive fewer government benefits. Of course, the effects of job loss go in the opposite direction. ${ }^{40}$

These changes might be of interest to local policymakers. If benefits decline, then to the extent that these benefits come from the federal (or state) government, there would be less money coming into a city. As a prime example, the federal Earned Income Tax Credit (EITC) has grown into the largest program for providing income support to lower-income families (Blank, 2002). As a consequence, when a worker's earnings rise, the inflow of federal dollars via the EITC can decline. On the other hand, the expenses for some benefits paid by the local government would fall.

The CPS data give us information on public assistance/welfare, food stamps (SNAP), free or reduced-price hot lunches at school, public housing, and energy assistance. ${ }^{41}$ The evidence in Table 9 generally indicates that higher living wages reduce support from or participation in these programs. Higher business assistance living wages are associated with significantly lower probabilities that families receive welfare, live in public housing, or receive energy assistance. Although there are both winners and losers from a higher living wage, the winners far outnumber the losers, ${ }^{42}$ apparently on net reducing the number of beneficiaries. The point estimates also suggest that living wages reduce payments from welfare or food stamps, and reduce the likelihood of children getting free or reduced-price hot lunches, but these estimates are generally not statistically significant.

\section{Conclusions}

The goal of this paper was to provide updated evidence on the effects of living wage laws in U.S. cities, relative to the earlier research on the first six or seven years of existence of these laws. The early round of research on living wages extended from 1995-2002, whereas the data we use in this paper potentially double the length of the sample period, to 2009, and nearly double the number of cities with living wages. As it turns out, however, there are some challenges to updating this evidence, as the CPS data on which it relies changed geographic coding systems in the mid-2000s, necessitating some "rolling up" of urban areas into larger areas to maintain consistency across the sample period - aggregation that in some cases appears to influence the estimates. The aggregation problems work against the goal of updating the evidence, making it more difficult to draw inferences beyond 2004 for the wage and employment analysis and 2003 for the family income analysis, although we also report the estimates extending as far as we can.

The focus is on the effects of living wages on low-wage or low-skill workers, and on lowincome families. Turning first to wages, the updated evidence continues to point to living wages increasing wages at the bottom of the wage distribution - for the purposes of this paper, in the bottom decile of the wage distribution. The point estimates to some extent indicate that the wage effects are stronger for business assistance than for contractor-only living wage laws. However, in the updated evidence the estimated wage effects, while uniformly positive, are not statistically significant. The preferred estimates taking account of both the updating and aggregation problem are that the elasticity of wages in the bottom 
Table 9 Estimated effects of living wages on income support and program participation, 1995-2003

\begin{tabular}{|c|c|c|c|c|c|c|c|}
\hline & \multicolumn{2}{|c|}{ Public assistance/welfare } & \multicolumn{2}{|c|}{ Food stamps } & \multicolumn{3}{|c|}{ Any benefits from: } \\
\hline & Value of benefits & Any benefits & Value of food stamps & Any benefits & Free or reduced-price hot lunch & Public housing & Energy assistance \\
\hline & (1) & (2) & (3) & (4) & (5) & (6) & (7) \\
\hline Sample mean & 145.53 & 0.037 & 154.93 & 0.079 & 0.103 & 0.030 & 0.021 \\
\hline \multicolumn{8}{|l|}{ Specification 1} \\
\hline \multirow[t]{2}{*}{ Log living wage, lagged 12 months } & -14.857 & 0.001 & -12.479 & 0.007 & $-0.019^{*}$ & $-0.017^{* *}$ & -0.009 \\
\hline & $(56.722)$ & $(0.011)$ & $(40.266)$ & $(0.015)$ & $(0.012)$ & $(0.008)$ & $(0.007)$ \\
\hline \multicolumn{8}{|l|}{ Specification 2} \\
\hline \multicolumn{8}{|l|}{ Business assistance living wage laws: } \\
\hline \multirow[t]{2}{*}{ Log living wage, lagged 12 months } & -96.483 & $-0.025^{* *}$ & -23.055 & -0.004 & -0.024 & $-0.032^{* *}$ & $-0.020^{* *}$ \\
\hline & $(67.362)$ & $(0.011)$ & $(48.909)$ & $(0.019)$ & $(0.017)$ & $(0.013)$ & $(0.008)$ \\
\hline \multicolumn{8}{|l|}{ Contractor-only living wage laws: } \\
\hline \multirow[t]{2}{*}{ Log living wage, lagged 12 months } & 70.999 & $0.028^{* *}$ & -1.355 & 0.018 & -0.014 & -0.002 & 0.003 \\
\hline & $(71.827)$ & $(0.014)$ & (59.606) & $(0.021)$ & $(0.013)$ & $(0.008)$ & $(0.009)$ \\
\hline N & 157,048 & 157,048 & 157,048 & 157,048 & 157,048 & 157,048 & 157,048 \\
\hline
\end{tabular}

See notes to Tables 3 and 8 . All specifications have city-specific trends. The benefits variables are annual. The specifications for receipt of benefits are linear probability models. ${ }^{* * * \prime}\left({ }^{* * \prime}\right)$ superscript indicates estimate is statistically significant at five-percent (ten-percent) level. Reported standard errors are robust to nonindependence (and heteroscedasticity) within city cells (clustered by city). 
decile with respect to business assistance living wages is 0.051 , versus a slightly smaller 0.037 for contractor-only living wages.

With regard to employment, the estimates are - as theory would predict - uniformly negative. The preferred estimates are statistically significant, indicating that, for example, a $50 \%$ increase in a business assistance living wage reduces employment in the bottom decile of the skill distribution by 2.8 percentage points; the corresponding estimate for contractoronly living wages is 2.4 percentage points.

Looking at what is perhaps a good criterion with which to judge the efficacy of living wages, the updated evidence through 2009 continues to find - as did the earlier research that living wage laws can reduce urban poverty. The new evidence finds this effect only for business assistance living wage laws. Moreover, there is some ambiguity as to how strong this evidence is statistically. The estimated effect is statistically significant for the full extended sample period, indicating that a $50 \%$ increase in a business assistance living wage reduces poverty by 1.2 percentage points. But given concerns over the aggregation of urban areas, if we extend the estimates only to the time when the aggregation becomes necessary (2003 in this case), the estimate, while a shade larger, is no longer statistically significant.

All told, in our view this updated evidence is broadly consistent with the conclusions that Holzer's (2008) review of the earlier evidence reached - that living wages have modest benefits for some workers and modest costs for others, and may also result in modest reductions in poverty. And we would add that the latter conclusion is true only of business assistance living wage laws, and not of narrower contractor-only laws. Updating the evidence has led to some changes in the point estimates, and perhaps also introduced a bit more uncertainty because depending on which data one uses and for what period, the estimates sometimes change. But this overall conclusion is still quite consistent with the data. Living wages do reduce employment among the least-skilled workers they are intended to help. But they also increase wages for many of them. This implies that living wage laws generate both winners and losers among those affected by them, and the net effects lean toward modest reductions in urban poverty.

\section{Endnotes}

${ }^{1}$ In the United States the federal government sets a minimum wage. States can pass a higher minimum wage for the workers covered by the federal minimum wage, but not a lower minimum wage. They can pass any minimum wage for workers not covered by the federal minimum wage. The federal minimum wage covers most workers.

${ }^{2}$ See Table 1 in Neumark and Adams (2003a).

${ }^{3}$ In addition, living wage laws often impose a higher living wage if the employer does not provide health insurance to its workers. Whether such requirements increase health insurance coverage of workers remains unanswered.

${ }^{4}$ This is the central focus of research on minimum wages as well. For a comprehensive review of evidence on the employment effects of minimum wages, see Neumark and Wascher (2007). When we say that "economic theory predicts job losses," we are referring to the standard neoclassical theory of the firm. As discussed in Neumark and Wascher, there are other models where this prediction is less clear. However, the evidence is strongly consistent with the neoclassical model, in that most research on minimum wages confirms that they generate disemployment effects. 
${ }^{5}$ See Burkhauser et al. (1996) and Carrington and Fallick (2001).

${ }^{6}$ Many of these earlier studies were recently published in Pollin et al. (2008). These studies were often done by advocates for living wages. For example, Pollin et al. (2008) refer to the higher wages that "low-wage workers deserve" (p. 13, italics added), and view living wages as "a means through which we can both protest and formulate a concrete alternative to the economic injustices that have prevailed in the United States for over a generation" (p. 21).

${ }^{7}$ For a full discussion of the details regarding the econometric analysis, see Adams and Neumark (2005a).

${ }^{8}$ Most but not all living wage laws fall into one of these two categories.

${ }^{9}$ To be clear, an estimate so much below one estimate does not imply that the living wage is not enforced and hence does not increase wages of affected workers. Rather, the living wage only applies to a subset of the workers studied because there is no way to identify in the CPS data which workers are and are not covered. This issue is discussed more below.

${ }^{10}$ Given an average employment rate of about 0.4 for individuals in this range of the imputed wage distribution, if the estimated employment effect is compared with the estimated wage effect, the evidence indicates an employment elasticity with respect to the "realized" wage increase of $-1.9[(-5.3 / 0.40) / 7.0]$, larger than the -0.5 figure that is taken as a consensus in the labor demand literature (Hamermesh, 1993). This suggests that the estimated disemployment effect, insofar as it arises solely due to the "average" wage effect of living wages, is larger than would be expected. However, living wages may entail greater increases in projected future labor costs than the wage increase that identifies the typical labor demand elasticity, given their frequent indexation. Also, this elasticity focuses on one narrow category of workers rather than on labor overall, so substitution possibilities may be greater.

${ }^{11}$ We note that, for the most part, wage and employment effects above the 10th percentile of the wage or predicted wage distribution were weaker, although Neumark and Adams sometimes found hints of evidence of positive wage or employment effects between the $10^{\text {th }}$ and $50^{\text {th }}$ percentiles, consistent with substitution toward higher-skilled labor. (See Adams and Neumark, 2005a, Table 4.)

${ }^{12}$ Lester and Jacobs (2010), in a recent study, conduct the only other national analysis of business assistance living wages that parallels the Neumark and Adams research in conducting a before-and-after analysis of the effects of living wages in many cities. There is also a more limited study of the same type of living wage laws in California (Lester, 2011). As discussed in detail in Charles River Associates (2011), these studies have substantial limitations, aside from the inability of the data they use to distinguish low-skilled workers, as discussed below.

${ }^{13}$ For purposes of full disclosure, Neumark and Holzer have co-authored studies together. However, these were studies of affirmative action and not of living wages (or minimum wages).

${ }^{14}$ These criticisms are still aired frequently by organizations advocating for living wages. See, e.g., http://www.nelp.org/page/-/Justice/2011/AssessmentEDCStudyMay2011. pdf?nocdn=1 (viewed November 28, 2012).

${ }^{15}$ Fairris and Reich erroneously apply the overall estimated labor demand elasticity implied by the estimates, which is -2.6 , to the percentage increase in the living wage $(-2.60 \times 0.35=-0.91)$. But the -2.6 elasticity is the percentage change in employment 
for a $1 \%$ increase in the overall wage paid to affected workers. Since the elasticity of wages with respect to the living wage is small (0.067), the correct estimate calculated this way has to multiply -2.6 by 0.067 , yielding a much smaller number.

16 They write, "The City of Los Angeles' enforcement database was used to identify contracts with low-wage workers. The lists of firms were stratified by industry and occupational groupings before a random sample of employers was taken" (p. 12).

17 This quote is at odds with Pollin et al's claim (in a book of which Luce is a co-author) that "the findings that city administrations have applied the living wage business-assistance clauses to few, if any, firms, is consistent with Luce's (2004) extensive study on the successes and pitfalls of implementing living wage ordinances" (2008, p. 246).

${ }^{18}$ Of course another possibility is that because of industries they are in, the labor demand elasticities of business assistance recipients are inherently different. For example, suppose the typical contractor is in the garbage business, and the typical business assistance recipient is in retail. The elasticity of demand for labor in retail may be much greater because it is easier to substitute away from labor - for example, just allowing slightly longer lines - whereas in the garbage business there may be little flexibility with regard to the labor input, and the cost of labor may be low relative to the cost of capital, energy, etc.

${ }^{19}$ Pollin et al. (2008) (echoing Brenner et al., 2002) make a particularly misleading argument about business assistance coverage. They assert that the Neumark and Adams estimates of the effects of business assistance living wage laws are flawed because they define "potentially covered workers as all private sector workers (usually about 90-95 percent of the workforce)" (p. 240). This is a a mischaracterization. Neumark and Adams (2003a) tried to substantiate their results indicating that business assistance living wages increased wages of low-wage workers by attempting to distinguish workers who could not be covered from those who could potentially be covered. For business assistance laws, an upper bound estimate would include the entire private sector - upwards of $90 \%$ of the workforce. They clearly stated that they "chose the broadest definitions of potential coverage, so as not to exclude those that are potentially affected. At best, we identify those workers who could in principle be covered; actual coverage rates should be much lower than those we report" (Neumark and Adams, 2003a, p. 509). Pollin et al. report results reclassifying workers as covered by business assistance living wage laws only if they work in service industries likely to be covered by contractor provisions. They then report as an independent finding that the Neumark and Adams results were reversed, with positive wage effects for the uncovered. The empirical finding is meaningless, however; what Pollin et al. have done, essentially, is to flip the classifications of workers as potentially covered by business assistance versus uncovered, by removing from the potentially covered group all those outside the services industry. Not surprisingly, then, the original results also flip. (Pollin et al. also never explain why workers potentially covered by business assistance living wage laws should be restricted to those in services, since it is the contractor living wage laws that generally apply only to the services industry.)

${ }^{20}$ Brenner et al. assumed that Neumark and Adams required 25 (or 30) covered workers in their sample from Los Angeles-Long Beach to obtain reliable estimates, and based on the number of sampled workers and a coverage estimate, suggested that the odds of getting 25 workers was 1 in 500,000 (falling to 1 in 244,000,000 for 30 workers). The Los Angeles living wage law took effect in April 1997; hence, if the CPS samples 5,000 wage earners per year (as Brenner et al. say), the relevant sample size would be about 18,750 (5,000 multiplied 
by the 3-3/4 years that the living wage law was in effect in the original sample in Neumark and Adams (2003a). In this case, based on their coverage estimate, the expected number of covered workers in the sample would be 31 (1 more than the number that they argue Neumark and Adams would meet or exceed with a probability of only 1 in 244,000,000).

${ }^{21}$ Of course one can ask whether there is a better alternative data set. Lester and Jacobs' (2010) recent study uses the National Establishment Time Series (NETS), a longitudinal data set on the universe of business establishments in the United States, which has the advantage of identifying the cities in which business establishments are located. However, the NETS has information only on total employment counts, not on employment of workers in different skill groups or their wages. As a result, Lester and Jacobs can only test for aggregate employment effects - either for the private sector as a whole, or specific industries that might be more affected by business assistance living wage laws. They cannot estimate wage or employment effects on the least skilled, nor can they say anything about how living wages affect families; hence the NETS data cannot address the central policy question of whether living wage mandates ultimately help or hurt those whom they affect.

${ }^{22}$ The 2004 MORG file contains some CBSA codes and some MSA codes, suggesting that the change to CBSA occurred mid-year 2004 in the MORG file, while the ASEC definition change occurred distinctly between the 2004 and 2005 year files. The crosswalk was thus applied to the 2004-2009 MORG files, and the 2005-2009 ASEC files.

${ }^{23}$ After this matching, 14 of the 275 CBSA codes that remained do not match to any MSA or PMSA. These are generally smaller cities, such as Coeur D'Alene, ID and Bend, OR. However, these unmatched CBSAs are not relevant for our analysis, because we restrict the data to urban areas with a minimum number of observations (described below), and none of the unmatched CBSAs meet the criterion for the minimum number of observations.

${ }^{24}$ See http://www.census.gov/popest/cities/ (viewed November 9, 2010).

${ }^{25}$ We had this information on many cities from the earlier research. But we wanted to confirm that information and to use a consistent method of obtaining information on living wages for the entire sample period.

${ }^{26}$ We also used the search bar provided on the city website to search for items containing "living wage," "living," "wage," "livable," "equal wage," and any ordinance information collected from the current code.

${ }^{27}$ An appendix table available from the authors lists the living wage levels by year for these cities. Some cities passed laws that were never implemented, for instance because of a subsequent court decision (see Adams and Neumark, 2005b). These living wage laws are not included.

${ }^{28}$ We collected extensive information on other characteristics of living wage laws, with the goal of estimating effects of different types of laws. However, it turned out to be fruitless to estimate the effects of many of these features of living wage laws, because there simply are not that many cities with living wage laws, and once we look for specific features of the laws, there is at most a handful of them. This issue highlights why simulation studies can add complementary information about the likely effects of a specific living wage law, given sufficiently detailed data. An appendix table available from the authors lists these living wage characteristics for the 26 living wage cities in our analysis sample.

${ }^{29}$ The maximum is the minimum wage if there is no living wage. 
30 The effects of living wages (and minimum wages) are estimated contemporaneously, and at six- and 12-month lags. Typically the effects show up at a lag of 12 months, so we highlight these estimates in this paper. Living wage effects may arise with a lag for a couple of reasons. First, in many cities there was an initial period of ambiguity and little or no implementation and enforcement between the time when a living wage law was passed and city administrators began to implement the law in a serious way (e.g., Sander and Lokey, 1998). Second, living wages are not immediately applied to all businesses. For example, for contractors they are typically only applied as contracts are renewed, and for business assistance recipients, they are usually only applied to new recipients of assistance. More generally, employers would not be expected to respond immediately to changes in labor costs, as they make the adjustments necessary to use less low-skilled labor. However, this last consideration should apply to employment effects, but not wage effects.

${ }^{31}$ This is a standard panel data approach, although a recent paper (Neumark et al. 2012) shows that sometimes the restriction to linear trends can generate biased estimates.

${ }^{32}$ Recall that there are two criteria for central or principal cities. First, we selected all central or principal cities that had a population of at least 250,000 residents according to 2000 Decennial Census data. Second, if no city in the metropolitan area had at least 250,000 residents, we included the largest city in the metropolitan area. When there is more than one such city, we assign a living wage based on a population-weighted average across the MSAs/PMSAs of the central or principal cities.

${ }^{33}$ If there is some disemployment, then presumably some of the lowest-wage workers lose their jobs (or do not get hired), in which case, by construction, wages in the lowest decile must increase. Thus, a precise estimate of a wage effect of zero would be puzzling given the evidence of disemployment effects. However, we instead find a relatively imprecise estimate of a positive wage effect.

${ }^{34}$ Effects of mandated wage floors on wages above the floor are also sometimes interpreted as "ripple effects" to capture more direct effects on wages as, for example, employers preserve wage spreads between workers.

35 This same point helps explain why it is in no way contradictory to find that living wages reduce poverty (as reported below) but minimum wages do not (Wu et al., 2006; Neumark et al., 2005). The gains and losses from living wages may be of different magnitudes, affect different workers, and fall at different points in the distribution of family income than do the gains and losses from minimum wages.

${ }^{36}$ Neumark and Adams (2003a) wrote: "Living wages have only been in existence for a short time, however, and as yet in a limited number of cities. More work will need to be done to evaluate whether the evidence we find holds up in a larger sample of cities that have adopted such legislation over a longer period of time" (p. 520).

37 This analysis extends through 2003 (and not 2004, the last year before the geographic classification changed), because the ASEC files cover the previous year.

${ }^{38}$ We re-estimated the model in column (6) using the larger sample of 91 MSAs/ PMSAs that does not restrict attention to the subsample for which we do the wage analysis. The results were very similar.

${ }^{39}$ Earlier work on this question includes Shaviro (1999) and Toikka et al. (2005), although neither looks at longitudinal evidence on what happens when living wages are implemented. 
Indeed, there is not really any disagreement between those on the two sides of the living wage debate about the basic proposition that the effects of living wages on families are dissipated because of high implicit marginal tax rates on low-income families. For example, Pollin et al. (2008, Ch. 7) study how the proposed Santa Monica living wage would have affected families, based in part on survey evidence. As they acknowledge, "when living wage laws raise a family's earned income, it means that government support for which such families are eligible correspondingly declines while their tax obligations rise. This means that some significant share of the benefits from living wage standards becomes a leakage - with government agencies, rather than low-wage workers and their families, becoming the beneficiaries of the law" (p. 108). And, in fact, the magnitude of this "leakage" (which is exactly the same as the implicit marginal tax rate) is in the range of that estimated by Toikka et al. (2005). In particular, for Santa Monica, Pollin et al. estimate that only $50 \%$ of the increased earnings actually benefits families, or that the marginal tax rate is 50\%. Although not exactly comparable, Toikka et al. report a marginal tax rate of $48 \%$ for Los Angeles (Table 6).

40 Note that the estimates of the effects of living wages on poverty take account of transfer income but not non-cash benefits or the EITC.

41 The CPS also has information on participation in WIC but only for a limited number of years; and eligibility for WIC is determined by a number of criteria unrelated to income.

42 In a simulation study of the effects of a proposed living wage for New York City, Neumark et al. (forthcoming) predict that winners would outnumber losers by a ratio of nearly six to one.

Competing interest

The Journal of Labor Policy is committed to the IZA Guiding Principles of Research Integrity. The authors declare that they have observed these principles.

\section{Acknowledgement}

This paper is drawn from a larger study conducted by Charles River Associates, funded by the New York City Economic Development Corporation (Charles River Associates, 2011). The views expressed are those of the authors and do not reflect the views of Charles River Associates, the City of New York, its Office of Management and Budget, or the New York City Economic Development Corporation. We are grateful to Daniel Hamermesh for many helpful comments.

Responsible editor: Juan Francisco Jimeno

\section{Author details}

${ }^{1}$ UCI, NBER, and IZA, Irvine, CA, USA. ${ }^{2}$ Charles River Associates, Tallahassee, FL, USA. ${ }^{3}$ Charles River Associates, Salt Lake City, UT, USA.

Received: 26 October 2012 Accepted: 4 December 2012

Published: 27 December 2012

\section{References}

Adams S, Neumark D (2004a) "The economic effects of living wages: a provisional review." Urban Aff Rev 40:210-45 Adams S, Neumark D (2004b) "A decade of living wages: What have we learned?" California Economic Policy, 1(1), July. Public Policy Institute of California, San Francisco

Adams S, Neumark D (2005a) "Living wage effects: New and improved evidence." Econ Dev Q :80-102

Adams S, Neumark D (2005b) "The effects of living wage laws: evidence from failed and derailed living wage campaigns." J Urban Econ 58:177-202

Blank RM (2002) "Evaluating welfare reform in the United States." J Econ Lit 40:1105-66

Brenner MD, Wicks-Lim J, Pollin R (2002) "Measuring the Impact of Living Wage Laws: A Critical Appraisal of David Neumark's "How Living Wage Laws Affect Low-Wage Workers and Low-Income families". Political Economy Research Institute Working Paper No. 43. Political Economy Research Institute, Amherst, MA

Burkhauser Richard V, Couch KA, Wittenburg DC (1996) "Who Gets What" from Minimum Wage Hikes: A Re-Estimation of Card and Krueger's Distributional Analysis in 'Myth and Measurement: The New Economics of the Minimum Wage.' Ind Labor Relat Rev 49:547-52

Carrington WJ, Fallick BD (2001) "Do some workers have minimum wage careers?". Mon Labor Rev 124:17-27

Cervero R (2002) "Reverse Commuting and Job Access in the United States." Unpublished paper, University of California, Berkeley 
Charles River Associates (2011) "The Economic Impacts on New York City of the Proposed Living Wage Mandate." Available at http://www.nycedc.com/NewsPublications/Studies/Documents/CombinedReportLivingWagelmpacts. pdf (viewed December 13, 2011)

Fairris D, Bujanda LF (2008) "The dissipation of minimum wage gains for workers through labor-labor substitution: evidence from the Los Angeles living wage ordinance." South Econ J 75:473-96

Fairris D, Reich M (2005) "The impacts of living wage policies: introduction to the special issue." Ind Relat 44:1-13

Fairris D, Runsten D, Briones C, Goodheart J (2005) Examining the Evidence: The Impact of the Los Angeles Living Wage Ordinance on Workers and Businesses. Los Angeles Alliance for a New Economy, Los Angeles

Frey WH, Wilson JH, Berube A, Singer A (2004) "Tracking Metropolitan America into the $21^{\text {st }}$ Century: A Field Guide to the New Metropolitan and Micropolitan Definitions." The Brookings Institution Metropolitan Policy Program, Washington DC

Hamermesh DS (1993) Labor Demand. Princeton University Press, Princeton, NJ

Holzer HJ (2008) "Living Wage Laws: How Much Do (Can) They Matter?". Discussion Paper, Brookings Institution Metropolitan Policy Program, Washington, DC, December

Lester TW, Jacobs K (2010) "Creating Good Jobs in Our Communities: How Higher Wage Standards Affect Economic Development and Employment". Center for American Progress Action Fund, Washington, D.C.

Lester WT (2011) "The impact of living wage laws on urban economic development patterns and the local business climate: evidence from California cities." Econ Dev Quart 25:237-54

Luce S (2004) Fighting for a Living Wage. Cornell University Press, Ithaca, NY

Neumark D, Adams S (2003a) "Do living wage ordinances help reduce urban poverty?". J Hum Resour 38:490-521

Neumark D, Adams S (2003b) "Detecting effects of living wage laws." Ind Relat 42:531-64

Neumark D, Wascher W (2007) "Minimum wages and employment." Foundations Trends Microeconomics 3:1-186

Neumark D, Schweitzer M, Wascher W (2005) "The effects of minimum wages on the distribution of family incomes: a nonparametric analysis." J Hum Resour 40(4):867-94

Neumark D, Salas JM, William W (2012) "Revisiting the Minimum Wage-Employment Debate: Throwing Out the Baby with the Bathwater?" Unpublished paper, UCl

Neumark D, Thompson M, Brindisi F, Koyle L, Reck C. Simulating the Economic Impacts of Living Wage Mandates Using New Public and Administrative Data: Evidence for New York City. Forthcoming in Economic Development Quarterly.

Pollin R, Brenner M, Wicks-Lim J, Luce S (2008) A Measure of Fairness: The Economics of Living Wages and Minimum Wages in the United States. ILR Press, Ithaca, NY

Sander RH, Lokey S (1998) "The Los Angeles living wage in operation: a preliminary evaluation." Calif Labor Employ Q 12(4):5-7

Shaviro DN (1999) Effective Marginal Tax Rates on Low-Income Households. Employment Policies Institute, Washington, D.C.

Toikka R, Yelowitz A, Neveu A (2005) "The "poverty trap" and living wage laws." Econ Dev Q 19:62-79

Wu X, Perloff JM, Golan A (2006) "Effects of government policies on urban and rural income inequality." Rev Income Wealth 52:213-35

doi:10.1186/2193-9004-1-11

Cite this article as: Neumark et al:: The effects of living wage laws on low-wage workers and low-income families:

What do we know now?. IZA Journal of Labor Policy 2012 1:11.

\section{Submit your manuscript to a SpringerOpen ${ }^{\circ}$ journal and benefit from:}

- Convenient online submission

- Rigorous peer review

- Immediate publication on acceptance

- Open access: articles freely available online

- High visibility within the field

Retaining the copyright to your article

Submit your next manuscript at $\boldsymbol{\sim}$ springeropen.com 